Victor Aulin - Andrii Hrynkiv - Oleg Lyashuk - Yuriy Vovk - Sergii Lysenko - Dmytro Holub - Taras Zamota Andrii Pankov - Mariana Sokol - Vadym Ratynskyi - Olena Lavrentieva

\title{
INCREASING THE FUNCTIONING EFFICIENCY OF THE WORKING WAREHOUSE OF THE "UVK UKRAINE" COMPANY TRANSPORT AND LOGISTICS CENTER
}

Competition in the field of logistics and individual transport services requires the constant analysis of logistics chains and their individual links. Given analysis enables implementation of new approaches to logistics companies and networks trade marketing in the offtake of certain types of goods. Industrial and commercial enterprises have to expand their trade and economic relations with other regions with the aim to provide the necessary sales volumes in the domestic market of regions and to go beyond it. Integration of the country's economy and the free trade policy orientation greatly simplify the task of establishing the free trade and economic relations between producers and consumers. However, there is a question of how quickly and efficiently; with minimal logistics costs, the goods at the right region of the customer should be delivered.

The experiment on a one-storey closed warehouse No 3 of Brovary "UVK Ukraine", where a process of the crossdocking warehousing, with subsorting from a warehouse, has been conducted. The warehouse mainly works on trading networks. The loading of the warehouse has been performed with the input flow intensity within (12.3 ... 23.56 (t/h)). During the experiment, the number gain of loading and unloading machines (Electrostacks Reath Track OMG NEOS LAT 3.0) a pcs in the process of unloading, loading and moving consignments, has been examined. In addition, the increasing number of workers employed in non-mechanized forms of work, such as receiving and stacking cargo in the reception area (moving the relevant consignments to designated areas of the reception area and its arrangement), which in total is an increase of 4 employees in the technological process of the warehouse operation, has been investigated during the experiment. The growing of labor and mechanized resources makes it possible to better organize the work of the warehouse, reduce total costs and increase cargo output flow. Conducting the process of warehouse work optimization on the formed technology and corresponding labor and mechanized resources caused an increase of its efficiency. It has been found that the optimal values of intensity of the incoming cargo flow will be 17.93 (t/h); the number of employees engaged in non-mechanized labor - 12 workers, and loading and unloading machines - 3 (pcs). Under such conditions, the warehouse functioning according to the desirability level will reach value 0.792. In this case, the cost value of warehouse work is 181.07 US\$/h and cargo output flow intensity is $10.23(\mathrm{t} / \mathrm{h})$. Results of experimental studies have shown that implementation of the proposed method of increasing the efficiency of warehouse work, based on the company "UVK Ukraine" may, on average, achieve a total cost reduction of $17.2 \%$ and an increase in output flow by $34.6 \%$ and the input flow by $10.3 \%$.

Keywords: warehouse logistics, transport and logistics center, labor resources, loading and unloading machines, warehouse, cargo flow, costs, optimization

\section{Introduction}

The current state of the logistics market development of any country, including Ukraine, depends on the level of its economy. The volume of services provided in the field of logistics directly depends on the activity level of their customers, the dynamics of production, domestic and foreign trade. For example, in the European Union (EU) countries, the logistics sector in its broadest sense is ranked as the third among the economic sectors. Underestimating the role of logistics as a factor of influence on the efficiency and competitiveness of the economy, worsens Ukraine's position in international rankings. Thus, Ukraine in 2019 in the World Bank's Logistics Performance Index (LPI) is ranked 67 in the world, [1]. One should consider that the logistic component's share in the gross domestic product

Victor Aulin ${ }^{1}$, Andrii Hrynkivi, Oleg Lyashuk ${ }^{2}$, Yuriy Vovk ${ }^{2, *}$, Sergii Lysenko ${ }^{1}$, Dmytro Holub ${ }^{1}$, Taras Zamota ${ }^{1}$, Andrii Pankov ${ }^{1}$, Mariana Sokol ${ }^{3}$, Vadym Ratynskyi ${ }^{4}$, Olena Lavrentieva ${ }^{5}$

${ }^{1}$ Department of Maintenance and Repair of Machines, Central Ukrainian National Technical University, Kropyvnytskyi, Ukraine ${ }^{2}$ Department of Automobiles, Ternopil Ivan Puluj National Technical University, Ukraine

${ }^{3}$ Foreign Languages Department, I. Ya. Gorbachevskyy Ternopil National Medical University, Ukraine ${ }^{4}$ Department of Accounting and Taxation, Ternopil Ivan Puluj National Technical University, Ukraine

${ }^{5}$ Department of General Technical Sciences and Vocational Training, Kryvyi Rih State Pedagogical University, Ukraine

*E-mail of corresponding author: vovkyuriy@ukr.net 
(GDP) is $11-16 \%$ in developed countries (in the EU and the United States - 13-17\%, in China - 25\%, in Japan - 7\%). As for Ukraine, most experts relate the economy of the country to the level of the "third world" countries, in which logistics costs can reach $41 \%$ of the GDP. This figure in Ukraine ranges from 31 to $34 \%$. At the same time, $69 \%$ of logistics costs accounted for transport (6.8 bln US\$), 24\% for warehousing (2.3 bln US $\$$ ) and about $6 \%$ - for logistics flow management ( 0.6 bln US\$) [1-2]. Therefore, one of the main areas of the modern transport policy is transition to the transport logistics in the transport and logistics system (TLS). TLS allows to provide comprehensive services to consumers of transport services, to create conditions for the combined transport development, to reduce the environmental burden on the environment [3]. The TLS structure should consist of a set of interconnected elements interaction at the regional and local levels. Regional distribution centers, terminal complexes, transport and logistics centers (TLCs) are the main system elements of transport infrastructure objects [4].

The relevance of organization and increase of efficiency of the transport and logistics centers is significantly growing. This is evidenced by existence and creation of new large, modern companies that specialize in this type of cargo delivery organization. They compete with each other, offering customers better, more economical, faster and better ways of processing orders, both domestically and internationally. This necessitates the development of efficient warehouse technologies and the organization of warehouse operations and logistics management.

\section{Literature review}

Taking into consideration current trends in development of the logistics services, it can be stated that the TLC have become the basic elements of the cargo management and cargo flows [5]. In general, such centers play a coordinating and distributive role in cargo transportation. Introduction of the new modern technologies necessitates creation of a network of TLC infrastructural objects that perform functions of interaction between types of transport and organization of material distribution in the economic region [6]. They are the basic foundation of material flow management that provide interconnection with senders, consumers, carriers, etc.

Major trends, such as timeliness, containerization and e-commerce, lead to a steady increase in the volume of goods that have to be transported in accordance with regulated delivery schedules [7]. Supply chains in this case are formed in such a way as to use fully adaptive storage systems as one of the main components of the transportation process [8]. The baggage handling at airports, mixed with inclined conveyor trays in the distribution centers of the postal industry, warehouses formation of retailers consignments through implementation of the e-commerce is an example of the most successful implementations of such warehouse complexes [9]. Because of the diverse logistical and organizational problems associated with design and management of individual warehouses with different systems of their warehouse functions it is difficult to describe the wide range of issues and various options for solving them [10].

The warehouse logistics is a functionally important stage in warehouse operations and it has a direct impact on cost and performance in the supply chain [11-13]. Due to inefficient operation of the warehouse complex, freight and logistics companies may experience significant inconvenience associated with the expectation between arrival and shipment [14]. This, in turn, leads to unjustified costs for the company in the form of a delay fee (fine for delayed transportation and additional costs for keeping the truck driver in overtime) and delayed delivery of subsequent orders [15]. In addition, long idling trucks in queues is not environmentally sustainable as it increases the concentration of carbon dioxide [16-18], so it is advisable to organize transport and storage complexes with a standardized loading and a warehouse work efficiency. The main aim of transport and logistics centers is to minimize the cost of logistics centers operating and to reduce the cost of goods transportation $[1,19]$. Implementation of the short-term strategies for realization of the cargo service functions in the transport and logistics complex will reduce logistics costs and increase the capacity of the warehouse [20]. The modeling approach and proposed warehouse scheduling rules are pre-developed and can be adopted by any enterprise.

Within the framework of forming an efficient TLS system, 3PL - TLC operators and cargo shippers have been considered and the quality of logistics services has been evaluated. Thus, the current state of the market can be determined: $41 \%$ of logistics is in a state of stagnation; $30 \%$ - at the stage of formation and development; $18 \%$ - at the stage of formation; $1.8 \%$ - at the redistribution stage [21]. Consequently, customers and logistics providers seek to optimize costs, implement new technologies, improve the quality of logistics services and establish effective communication between customers and logistics providers to increase the loyalty level of the end consumers [22]. International companies in Ukraine suggest that imperfect legislation - 74\%; corruption factor - 51\%; customs work $59 \%$; poor quality of infrastructure - $62 \%$; lack of professional staff - 24\%; market monopolization - $14 \%$ are the main obstacles in development of the TLS market. Ukrainian companies also gave to the factors of imperfect legislation and corruption factors the first place - 58 and 57\%, then imperfect infrastructure - 49\%, difficulties in customs work - 45\%, problems with staff experience - $26 \%$, and monopolization - 17\%. Among the factors that can greatly influence the development of the TLS, experts point out to implementation of EU legal acts and regulations [1, 23-24].

Analysis of the complex interactions that occur between different components of the transport and logistics center is the main problem of warehouse work improving [25]. The basic condition is a uniform distribution associated with the loading and unloading work required for the flow of goods 
within the logistics network. Its analysis is performed using the Petri nets and sensitivity functions as the discrete event modeling and simulation structures [25-27]. The warehouse modeling work is aimed at identifying the innovative aspect of using both graph theory and elements of sensitivity theory [28-31] and statistical optimization [32-33]. With help of mathematical tools to support the functional characteristics of warehouse systems, their strengths and weaknesses have been identified. However, that aspect makes it possible to implement individual storage units for various technological processes. Therefore, it is desirable to identify the critical factors in the local logistics chain in the warehouse and to propose solutions to improve its efficiency [34]. Use of the warehouse database processing methods is well suited to set the basic characteristics of individual warehouse units. At the same time, the main logistic processes, involving both labor and machinery should not be damaged [35-36]. It should be noted that direct modeling of cargo flows together with quantitative analysis made it possible to identify delays in the logistics chain and to determine indicators that will allow increasing the efficiency of the resource usage. The last one will increase the productivity of warehouse work [30,37].

With significant growth of interest in the logistics enterprises efficiency, the need for transport and logistics centers arises even more, so adaptation and high efficiency of their work for the diverse needs of logistics agents is a priority at present [25]. Nevertheless, this requires efficient coordination of warehouse work and formation of the warehouse technological process with the minimum required number of operations for human and mechanized resources [32].

Properly organized technological process of the TLC operation should ensure: accurate and timely carrying out of quantitative and qualitative acceptance of goods; effective use of mechanization of loading-unloading and transport-warehouse works; consistent and rhythmic performance of warehouse operations, which contributes to the systematic loading of warehouse workers and creation of favorable working conditions; rational warehousing of goods ensuring maximum use of warehouse volumes and areas; safety of goods; clear organization of centralized delivery of goods.

The aim of this study was to develop a methodology for formation of the warehouse work rational technology organization and warehouse work optimization.

\section{Materials and methods of determining the rational technology of service orders}

The transport and technological process is an important part of the transport and logistics network (TLN). It must be implemented to successfully complete the entire range of work and reduce the cost of operations in the TLC. In addition, it must be based on advanced technology and advanced methods. Solution to this problem involves optimizing the production process for efficient organization of material flow management and reducing the cost of operating the TLC in TLN. A one-storey closed warehouse No 3 of Brovary "UVK Ukraine" has been chosen for the experiment, where a process of cross-docking warehousing with subsorting from a warehouse, has been implemented. The total area of the warehouse is $1080 \mathrm{~m}^{2}$ and its height is $9 \mathrm{~m}$. Type of storage: 4 tier shelve rack. The warehouse mainly works on trading networks. This warehouse is part of the TLS where goods can be transported as by road transport and by rail through the container platform of the TLS. The railway and highway connections are brought to the container platform. From the container platform the required containers have been sent to the warehouse reception area and, if it is necessary the completed containers from the warehouse departure area have been moved, to the TLC container platform and further transport is already formed.

The technological process of the studied warehouse complex TLC functioning has the following sequence of operations:

1) Arrival of cargo to the warehouse: preparation of technical means for receiving cargo, documents, familiarization of warehouse workers with the unloading plan;

2) Check of cargo packing integrity in the vehicle: fastenings and presence of appropriate seals and markings are checked, external damages are revealed;

3) Unloading of cargo using the loading and unloading mechanisms (LUM);

4) Cargo reception and stacking in the reception area: moving the respective consignments of cargo to the designated places of the reception area and its arrangement;

5) Cargo reception by quantity and quality: opening of container, counting by quantity and verification of documentation, culling;

6) Selection and transfer of cargo to the storage and completing area;

7) Storage of cargo in a warehouse in two modes (1-2.5 days, 2.5 and more);

8) Completing and sending from the storage and reception areas: a consignment is formed for the relevant order, the quantity of the cargo and the type of container is determined, packaging and sealing is carried out, documents are being prepared;

9) Moving the finished cargo unit to the departure area;

10) Verification of cargo by quantity and compliance with documents;

11) Loading of cargo into the vehicle and transfer of documents.

Determination of the effective work organization is carried out by setting a value - total costs, which form a plurality of values corresponding costs for each element of the process.

In the process of active experiment influence of factors has been investigated: $X_{1}$ - the input flow intensity; $X_{2}$ the number of employees and $X_{3}$ - the number of loading and unloading machines in the warehouse instead of 
Table 1 Formation of factors and their levels for experiment

\begin{tabular}{lcc}
\hline \multirow{2}{*}{ Factors } & \multicolumn{2}{c}{ Levels } \\
\cline { 2 - 3 } & Lower $(-1)$ & Upper $(+1)$ \\
\hline$X_{1}$ - cargo input flow intensity, $t / h$ & 12.3 & 23.56 \\
$X_{2}$ - the number of employees engaged in non-mechanized labor, empl. & 8 & 12 \\
$X_{3}$ - the number of loading and unloading machines, pcs. & 2 & 3 \\
\hline
\end{tabular}

organizational and economic components of the warehouse activity. The testimonials or resulting features of experiment are as follows: $\mathrm{Y}_{1}$ - total costs (US\$) $\rightarrow$ min; $\mathrm{Y}_{2}$ - cargo output flow intensity $(\mathrm{t} / \mathrm{h}) \rightarrow \max$. The set of factors and their levels are presented in Table 1.

For the experiment, it has been decided to investigate three factors and their two levels. The number of necessary experiments can be calculated by formula:

$N_{e}=2^{n f}$

where:

2 - number of levels,

$n_{f}$ - number of factors.

According to Equation (1) it was determined that it is necessary to carry out 8 experiments for solving the optimization problems. A plan for the full-scale experiment, indicating the levels and factors, as well as the response functions of the experiment, has been formed. In order to minimize the impact on response, experiments should be performed in random order.

The analysis of this experiment plan has been performed using portable software (Statistica v.10.0.1011.0). The processing of the experimental results began with the regression analysis, i.e. the model has been built and the unknown coefficients of the regression equation have been determined:

$$
\begin{aligned}
& Y=b_{0}+b_{1} \cdot\left(X_{1}\right)^{2}+b_{2} \cdot\left(X_{2}\right)^{2}+b_{3} \cdot\left(X_{3}\right)^{2}+ \\
& +b_{4} \cdot X_{1} \cdot X_{2}+b_{5} \cdot X_{1} \cdot X_{3}+b_{5} \cdot X_{2} \cdot X_{3}
\end{aligned} .
$$

It has been determined that effects of the interaction of factors, based on their nature and content, are virtually absent and therefore, they have not been included in the overall appearance of the model (2). The unknown constant coefficients of the regression equation have been determined using the least squares method. The obtained model coefficients can be obtained by the following formulas:

$$
\begin{aligned}
b_{0} & =\sum_{i=1}^{N} Y / N ; b_{j}=\sum_{i=1}^{N} Y_{i} / N ; \\
b_{j}{ }^{2} & =\sum_{i=1}^{N} Y_{i}\left(X_{j i}\right)^{2} / N ; \ldots
\end{aligned}
$$

Description of factors and response using the mathematical model (2) is characterized by a coefficient of determination, which should be at least 0.95 , for a qualitative description of the object of study. This coefficient is calculated by the formula:

$R^{2}=1-\frac{\sigma_{z l}^{2}}{\sigma_{Y}^{2}}=1-\left(\sum_{i=1}^{N}\left(Y_{i}-\hat{Y}_{i}\right)^{2} / \sum_{i=1}^{N}\left(Y_{i}-\bar{Y}_{i}\right)^{2}\right)$,

where:

$\sigma_{z l}^{2}, \sigma_{Y}^{2}$ - dispersion of regression residues, response, respectively

$Y_{i}, \bar{Y}, \hat{Y}_{i}$ - actual, average, estimated value of the response.

The standard error that characterizes the standard deviation of the studied regression coefficients from the mean is calculated by the formula:

$S_{b j^{r}}=\sqrt{\frac{\sum_{i=1}^{N}\left(Y_{i}-\hat{Y}_{i}\right)^{2}}{\sum_{i=1}^{N}\left(X_{i j}-\bar{X}_{j}\right)^{2}} \cdot \frac{1}{n-2}}$

where $n$ - sample volume.

From a statistical point of view the regression coefficients evaluation is carried out by Student's criterion. This compares the calculated value to the table at a given confidence level of 0.05 and the calculated average values of levels:

$\left|t_{\alpha, f}\right|=\left|\frac{b_{j^{r}}}{S_{b_{j^{r}}}}\right|>t_{\alpha / 2, f_{t b}}$,

where:

$b_{j^{r}}$ - estimated regression coefficients,

$\alpha$ - probability 0.95 ,

$f$ - average value of level.

With a significant regression coefficient, the Student's test is greater than a tabular one.

The calculation of the marginal error of deviation has been established from the following calculations:

$\Delta_{j^{r}}=t_{\alpha, f \cdot t b} \cdot S_{b^{r}}$.

The interval for each regression coefficient has been determined according to inequality:

$b_{j^{r}}-\Delta_{j^{r}} \leq b_{j^{r}} \leq b_{j^{r}}+\Delta_{j^{r}}$.

Mathematical model fit to the experimental data, that is, its adequacy has been defined by Fisher's criteria $F$. The calculation criterion should be greater than the table criterion:

$F=\frac{\sigma_{X}^{2}}{\sigma_{Y}^{2}}=\frac{R^{2}}{1-R^{2}} \cdot \frac{f_{2}}{f_{1}} \geq F_{\alpha, f \cdot t b l}$, 
where:

$\sigma_{X}^{2}=\left(\sum_{i=1}^{N}\left(X_{i}-\bar{X}\right)^{2}\right) / f_{1}$ - dispersion factor,

$f_{1}$ - degree average value,

$\sigma_{Y}^{2}=\left(\sum_{i=1}^{N}\left(Y_{i}-\bar{Y}\right)^{2}\right) / N-f_{1}-1$ - dispersion value,

$N$ - experiments number,

$R^{2}$ - determination coefficient.

To solve the optimization problem, the desirability function approach, introduced by E. Harrington, has been used [38]. This method has useful properties of continuity, monotony and smoothness. The method converts specific parameters to abstract numeric values. A logical function as the basis for the calculation has been used:

$d_{i}=\exp \left(-\exp \left(-Y_{i}\right)\right)$

where: $\mathrm{Y}$ - function value.

Function (10) is characterized by the two saturation portions $(d \rightarrow 0$ and $d \rightarrow 1)$ and a linear portion $(d \rightarrow 0.2$ and $d \rightarrow 0.63)$. For a better abstract representation of a function, it is necessary to break it into ranges where the specific values of the scale correspond to the studied indicators. To form multivariate optimization, the function is formed by the following equation:

$Z=\sqrt[n]{\prod_{i=1}^{n} d_{i}}$

Further study of this function should determine analysis of the investigated values and factors of the process. The value of the curve optimum condition is set outside the curve level, within these limits, the most relevant factor values are selected. The function method is visual.

To determine the objective function values, a warehouse restrictions system based on the experimental and organizational data with the relevant factors values have been studied. Thus, they have been determined during the statistics data analysis of the "UVK Ukraine" warehouse complex functioning.

$$
\left\{\begin{array}{l}
12.3 \leq X 1 \leq 23.56 \\
8 \leq X 2 \leq 12 \\
2 \leq X 3 \leq 3 \\
Y 1 \rightarrow \min \\
Y 2 \rightarrow \max
\end{array}\right.
$$

The research planning experiment of cargo flow at Brovary "UVK Ukraine" warehouse complex has been used to find the optimal conditions for the work organization. The following factors have been selected: the input flow intensity $(t / h) X_{1}$, the number of employees engaged in manual labor (work.) $\mathrm{X}_{2}$, number of loading and unloading machines of Reath Track OMG NEOS LAT 3.0 stackers (pcs.) $\mathrm{X}_{3}$. For this purpose, the experimental data normalization of cargo flows movement through the warehouse complex has been used. These operations are necessary to obtain reliable research data on changes in the cost of improving warehouse operations, namely the total cost $(\$) \mathrm{Y}_{1} \rightarrow$ min; the output flow intensity $(\mathrm{t} / \mathrm{h}) \mathrm{Y}_{2} \rightarrow \max$. For the experiment, the Brovary "UVK Ukraine"" warehouse No 3 (for household goods) has been loaded in accordance with the data shown in Equation (12) and the experiment plan below (one experiment one working day of the warehouse) during the period from $04 / 15 / 2019$ to $04 / 22 / 2019$. The value functions have been calculated as averages over the entire experimental warehouse operating day. Increasing the number of employees engaged in non-mechanized labor has been used on operations: cargo reception and stacking in the reception area (moving the respective consignments of cargo to the designated places of the reception area and its arrangement) by changing the number of employees from 1 to 2 ; cargo reception by quantity and quality: (opening of container, counting by quantity and verification of documentation, culling) by changing the number of employees from 1 to 2; completing and sending from the storage and reception areas (a consignment is formed for the relevant order, the quantity of the cargo and the type of container is determined, packaging and sealing is carried out, documents are being prepared) increase from 1 person to 3 employees. Increases in loading and unloading machines have been made by increasing the number of Reath Track OMG NEOS LAT 3.0 electric stackers on unloading, loading and moving consignments from 2 pieces to 3 . The full factorial experiment makes it possible for multiple measurements that meet certain conditions set optimal factors values. The number of measurements is 8 and the values of the factors are combined in all the possible variants. Advantages of a full factorial experiment are the simplicity of the solution of the task and the statistical redundancy of the number of measurements, which reduces the influence of errors of individual measurements on the estimation of unknown regression coefficients.

\section{Results}

\subsection{Study results of the proposed approach to organization rational efficiency increase of the warehouse work}

Based on the obtained and processed experimental data, a database has been formed (Table 2) to identify changes in the optimality criteria for the organization of a warehouse complex. The minimum and maximum values in the peak period of "UVK Ukraine" company have been used to form the flow of goods.

The experimental data processing using application software makes it possible to automate the calculations according to the formulas given. Regression analysis of the experimental results is shown in Tables 3 and 4, insignificant coefficients in the tables were not recorded. 
Table 2 Value of the input parameters of the experiment according to the basic variant during the peak load movement in the warehouse complex

\begin{tabular}{|c|c|c|c|c|c|}
\hline \multirow{3}{*}{ 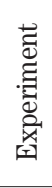 } & \multicolumn{3}{|c|}{ The levels of variation } & \multirow[b]{2}{*}{ Total costs, US\$ } & \multirow{2}{*}{$\begin{array}{l}\text { Cargo output flow } \\
\text { intensity, } \mathrm{t} / \mathrm{h}\end{array}$} \\
\hline & $\begin{array}{l}\text { Cargo input flow } \\
\text { intensity, t/h }\end{array}$ & $\begin{array}{l}\text { The number of } \\
\text { employees, empl. }\end{array}$ & $\begin{array}{l}\text { The number of loading and } \\
\text { unloading machines, pcs. }\end{array}$ & & \\
\hline & $\mathrm{X}_{1}$ & $\mathrm{X}_{3}$ & $\mathrm{X}_{4}$ & $\mathrm{Y}_{1}$ & $\mathrm{Y}_{2}$ \\
\hline 1 & 12.3 & 8 & 2 & 193.70 & 3.6 \\
\hline 2 & 23.56 & 8 & 2 & 162.49 & 6.3 \\
\hline 3 & 12.3 & 12 & 2 & 173.31 & 9.6 \\
\hline 4 & 23.56 & 12 & 2 & 140.29 & 8.4 \\
\hline 5 & 12.3 & 8 & 3 & 343.82 & 3.7 \\
\hline 6 & 23.56 & 8 & 3 & 273.05 & 7.7 \\
\hline 7 & 12.3 & 12 & 3 & 294.34 & 11.9 \\
\hline 8 & 23.56 & 12 & 3 & 221.85 & 12.05 \\
\hline
\end{tabular}

Table 3 The Regression analysis of experimental results for the optimizing trait $Y_{1}$

\begin{tabular}{|c|c|c|c|c|c|c|}
\hline \multicolumn{7}{|c|}{$\mathrm{R}^{2}=0.9988$ - the determination coefficient of the regression model of the experimental data } \\
\hline $\begin{array}{l}\text { Regression } \\
\text { coefficients }\end{array}$ & $\begin{array}{c}\text { Regression } \\
\text { coefficients } \\
\text { (value) }\end{array}$ & $\begin{array}{l}\text { Standard } \\
\text { error }\end{array}$ & $\begin{array}{l}\text { Student's } \\
\text { coefficient }\end{array}$ & $\begin{array}{l}\text { Significance level } p \text {, } \\
\qquad(p<0.05)\end{array}$ & $\begin{array}{l}\text { Average interval } \\
-95 \%\end{array}$ & $\begin{array}{c}\text { Average interval } \\
-95 \%\end{array}$ \\
\hline $\mathrm{b}_{0}$ & -23.80 & $38.86 \cdot 10^{-2}$ & 61.25 & $10.39 \cdot 10^{-3}$ & -28.74 & -18.87 \\
\hline$b_{1}$ & 25.51 & $1.43 \cdot 10^{-2}$ & 1787.49 & $3.56 \cdot 10^{-4}$ & 25.33 & 25.69 \\
\hline $\mathrm{b}_{2}$ & 3.71 & $33.82 \cdot 10^{-3}$ & 109.75 & $5.8 \cdot 10^{-3}$ & 3.28 & 4.14 \\
\hline $\mathrm{b}_{3}$ & 15.46 & $135.27 \cdot 10^{-3}$ & 114.31 & $5.56 \cdot 10^{-3}$ & 13.74 & 17.18 \\
\hline $\mathrm{b}_{4}$ & $-64.49 \cdot 10^{-2}$ & $9.99 \cdot 10^{-4}$ & 645.44 & $9.86 \cdot 10^{-4}$ & $-65.76 \cdot 10^{-2}$ & $-63.22 \cdot 10^{-2}$ \\
\hline$b_{5}$ & $-350.93 \cdot 10^{-2}$ & $3.99 \cdot 10^{-3}$ & 878.11 & $7.25 \cdot 10^{-4}$ & $356.01 \cdot 10^{-2}$ & $-345.85 \cdot 10^{-2}$ \\
\hline $\mathrm{b}_{6}$ & $-44.13 \cdot 10^{-2}$ & $11.25 \cdot 10^{-3}$ & 39.22 & $16.23 \cdot 10^{-3}$ & $-58.42 \cdot 10^{-2}$ & $-29.83 \cdot 10^{-2}$ \\
\hline
\end{tabular}

Table 4 The Regression analysis of experimental results for the optimizing trait $Y_{2}$

\begin{tabular}{ccccccc}
\hline \multicolumn{6}{c}{$\mathrm{R}^{2}=0.9988$} & - the determination coefficient of the regression model of the experimental data \\
\hline $\begin{array}{c}\text { Regression } \\
\text { coefficients }\end{array}$ & $\begin{array}{c}\text { Regression } \\
\text { coefficients } \\
\text { (value) }\end{array}$ & $\begin{array}{c}\text { Standard } \\
\text { error }\end{array}$ & $\begin{array}{c}\text { Student's } \\
\text { coefficient }\end{array}$ & $\begin{array}{c}\text { Significance level } \mathrm{p}, \\
(\mathrm{p}<0.05)\end{array}$ & $\begin{array}{c}\text { Average interval } \\
-95 \%\end{array}$ & $\begin{array}{c}\text { Average interval } \\
-95 \%\end{array}$ \\
\hline $\mathrm{b}_{0}$ & -21.584 & $21.59 \cdot 10^{-2}$ & 99.97 & $6.37 \cdot 10^{-3}$ & -24.33 & -18.84 \\
$\mathrm{~b}_{1}$ & $-62.28 \cdot 10^{-2}$ & $7.93 \cdot 10^{-3}$ & 78.56 & $8.1 \cdot 10^{-3}$ & $-72.35 \cdot 10^{-2}$ & $-52.20 \cdot 10^{-2}$ \\
$\mathrm{~b}_{2}$ & $282.67 \cdot 10^{-2}$ & $18.79 \cdot 10^{-3}$ & 150.46 & $4.23 \cdot 10^{-3}$ & $258.8 \cdot 10^{-2}$ & $306.55 \cdot 10^{-2}$ \\
$\mathrm{~b}_{3}$ & $899.01 \cdot 10^{-2}$ & $75.15 \cdot 10^{-3}$ & 119.63 & $5.32 \cdot 10^{-3}$ & $803.53 \cdot 10^{-2}$ & $994.5 \cdot 10^{-2}$ \\
$\mathrm{~b}_{4}$ & $4.94 \cdot 10^{-2}$ & $5.55 \cdot 10^{-4}$ & 89.00 & $7.15 \cdot 10^{-3}$ & $4.23 \cdot 10^{-2}$ & $5.65 \cdot 10^{-2}$ \\
$\mathrm{~b}_{5}$ & $11.77 \cdot 10^{-2}$ & $2.22 \cdot 10^{-3}$ & 53.00 & $12.01 \cdot 10^{-3}$ & $8.95 \cdot 10^{-2}$ & $14.59 \cdot 10^{-2}$ \\
$\mathrm{~b}_{6}$ & $-96.87 \cdot 10^{-2}$ & $6.25 \cdot 10^{-3}$ & 155.00 & $4.11 \cdot 10^{-3}$ & $-104.82 \cdot 10^{-2}$ & $-88.93 \cdot 10^{-2}$ \\
\hline
\end{tabular}

For a more accurate reflection of the experimental results, the mathematical regression model has been complicated to the second order. The factors did not interact, if the coefficient of determination was not lower than 0.95 . While analyzing data in Tables 3 and 4 , it is possible to conclude that all the included factors are statistically significant, as evidenced by the level of their significance. Therefore, the values of the coefficients can be included in the model that describes the process of composition at studied factors. In the general case, the regression equations have the form:

$$
\begin{aligned}
& Y_{1}=-23.80+25.51 \cdot\left(X_{1}\right)^{2}+3.71 \cdot\left(X_{2}\right)^{2}+ \\
& +15.46 \cdot\left(X_{3}\right)^{2}+64.49 \cdot 10^{-2} \cdot X_{1} \cdot X_{2}- \\
& -350.93 \cdot 10^{-2} \cdot X_{1} X_{3}-44.13 \cdot 10^{-2} \cdot X_{2} \cdot X_{3} \\
& Y_{2}=-21.584-62.28 \cdot 10^{-2} \cdot\left(X_{1}\right)^{2}+282.67 \cdot 10^{-2} \\
& \cdot\left(X_{2}\right)^{2}+899.01 \cdot 10^{-2} \cdot\left(X_{3}\right)^{2}+4.94 \cdot 10^{-2} \cdot X_{1} \cdot X_{2}+ \\
& +11.77 \cdot 10^{-2} \cdot X_{1} \cdot X_{3}-96.87 \cdot 10^{-2} \cdot X_{2} \cdot X_{3}
\end{aligned}
$$


Table 5 The dispersion analysis of the experimental data for the optimizing trait $Y_{1}$

\begin{tabular}{cccc}
\hline Coefficients & Dispersion & Fisher's criterion & Significance level $\mathrm{p},(\mathrm{p}<0.05)$ \\
\hline $\mathrm{b}_{1}$ & $2.68 \cdot 10^{3}$ & $26.49 \cdot 10^{6}$ & $12.4 \cdot 10^{-5}$ \\
$\mathrm{~b}_{2}$ & $2.56 \cdot 10^{3}$ & $25.34 \cdot 10^{5}$ & $4.0 \cdot 10^{-4}$ \\
$\mathrm{~b}_{3}$ & $5.38 \cdot 10^{3}$ & $53.15 \cdot 10^{5}$ & $2.76 \cdot 10^{-4}$ \\
$\mathrm{~b}_{4}$ & $4.21 \cdot 10^{2}$ & $41.66 \cdot 10^{4}$ & $9.86 \cdot 10^{-4}$ \\
$\mathrm{~b}_{5}$ & $7.81 \cdot 10^{2}$ & $77.10 \cdot 10^{4}$ & $7.25 \cdot 10^{-4}$ \\
$\mathrm{~b}_{6}$ & 1.56 & $1.53 \cdot 10^{3}$ & $1.62 \cdot 10^{-2}$ \\
\hline
\end{tabular}

Table 6 The dispersion analysis of the experimental data for the optimizing trait $Y_{2}$

\begin{tabular}{cccc}
\hline Coefficients & Dispersion & Fisher's criterion & Significance level $\mathrm{p},(\mathrm{p}<0.05)$ \\
\hline $\mathrm{b}_{1}$ & $11.25 \cdot 10^{3}$ & $1.09 \cdot 10^{2}$ & $1.42 \cdot 10^{-8}$ \\
$\mathrm{~b}_{2}$ & $92.02 \cdot 10^{3}$ & $8.98 \cdot 10^{2}$ & $1.42 \cdot 10^{-15}$ \\
$\mathrm{~b}_{3}$ & $10.44 \cdot 10^{3}$ & $1.01 \cdot 10^{2}$ & $2.41 .42 \cdot 10^{-8}$ \\
$\mathrm{~b}_{4}$ & $30.50 \cdot 10^{3}$ & $2.97 \cdot 10^{2}$ & $9.17 \cdot 10^{-12}$ \\
$\mathrm{~b}_{5}$ & $30.75 \cdot 10^{3}$ & $3.00 \cdot 10^{2}$ & $8.62 \cdot 10^{-12}$ \\
$\mathrm{~b}_{6}$ & $71.44 \cdot 10^{3}$ & $6.97 \cdot 10^{2}$ & $1.27 \cdot 10^{-14}$ \\
\hline
\end{tabular}

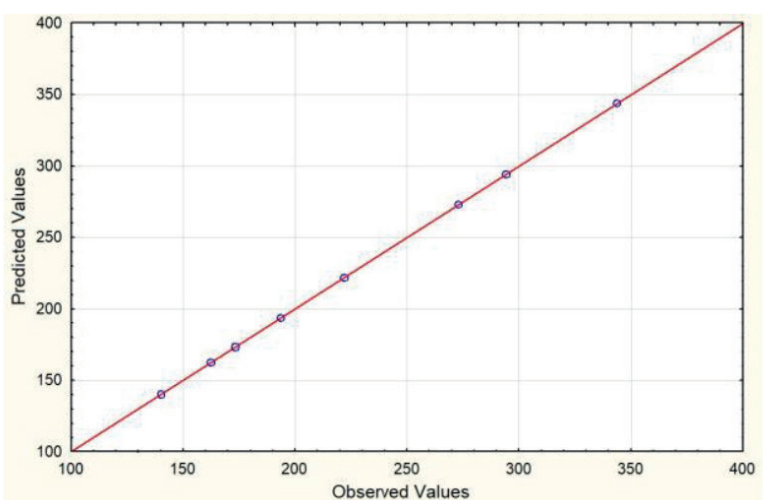

a)

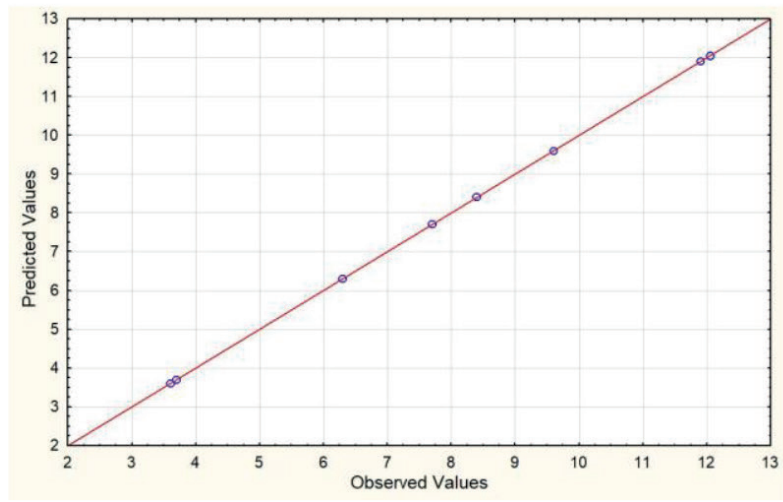

c)

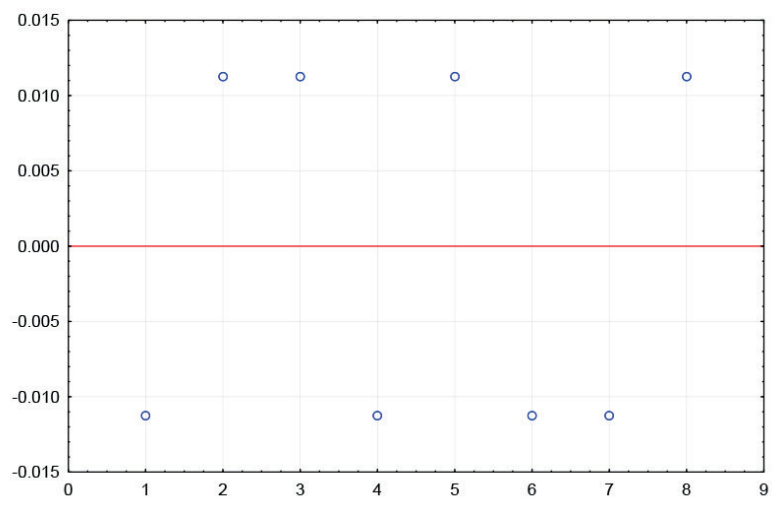

b)

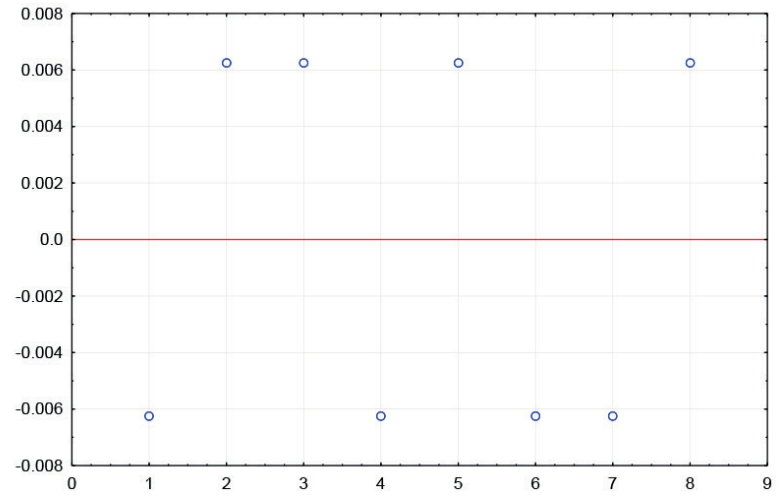

d)

Figure 1 Graphical display of the projected and observed balances and estimation of their magnitude: a) and b) - for the total cost function; c) and d) - for the output flow intensity

To assess the adequacy of these models, a variance analysis of the obtained experimental data has been performed and Fisher's criterion has been determined. Realization of the dispersion analysis is reflected in Tables 5 and 6 .

From Tables 5 and 6 it can be seen that the factors included in the mathematical model (13), (14) adequately describe the studied process of the warehouse functioning, so the significance level $\mathrm{p}$, for each factor is below the allowable level of 0.05 .

Visually estimate residual dispersion between the obtained and estimated values by regression Equations (13) and (14). It should be noted that significant dispersion of $10 \%$ of the maximum predicted values should not be present 


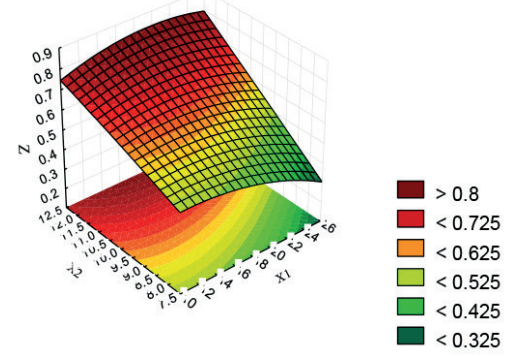

a)

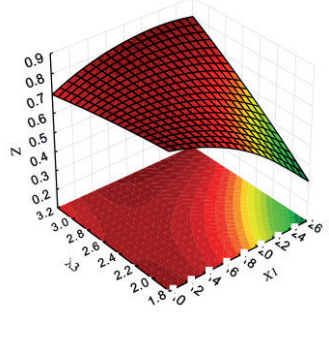

b)

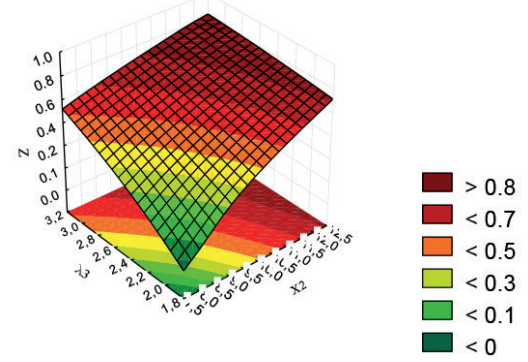

c)

Figure 2 Graphic representation of surfaces value on the scale of desirability of the studied warehouse work: a) dependence of $Z$ on $X 1$ and $X 2 ; b$ ) dependence of $Z$ on $X 1$ and $X 3$; c) dependence of $Z$ on $X 2$ and $X 3$

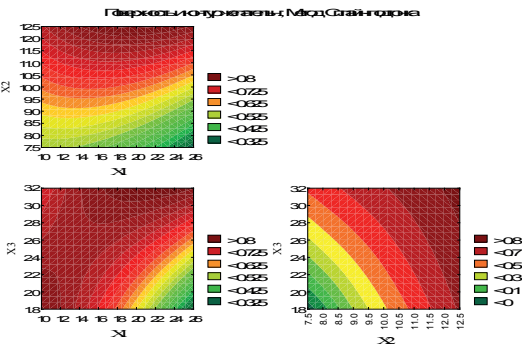

a)
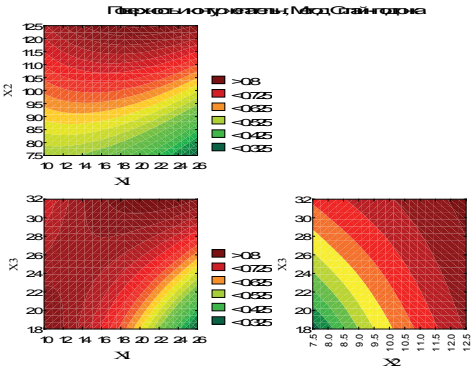

b)
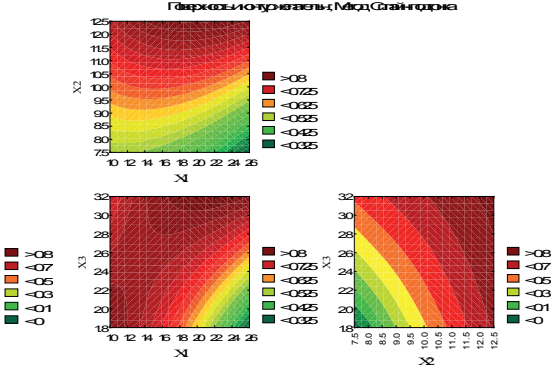

c)

Figure 3 Graphical representation of value levels on the scale of the investigated tribological supplement: a) dependence of $Z$ on $X_{1}$ and $X_{2} ; b$ ) dependence of $Z$ on $X_{1}$ and $X_{2}$; c) dependence of $Z$ on $X_{2}$ and $X_{3}$

$\mathrm{X} 1$
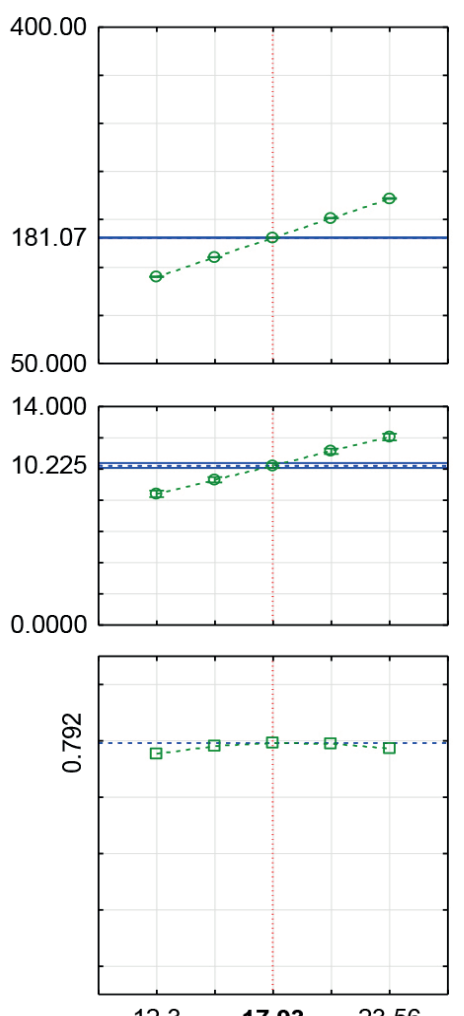

$\mathrm{X} 2$
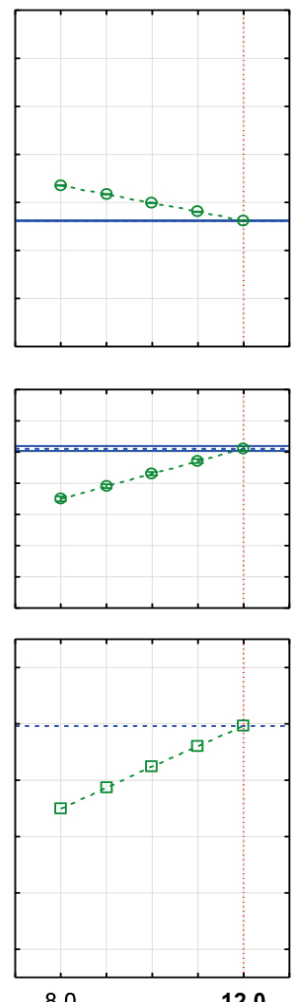

X3
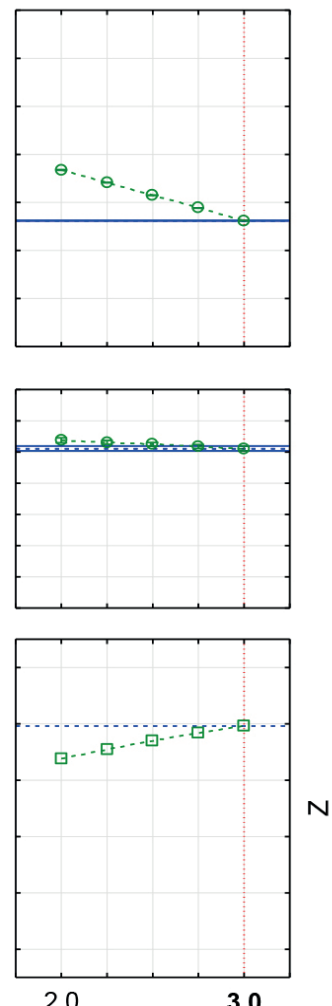

Z
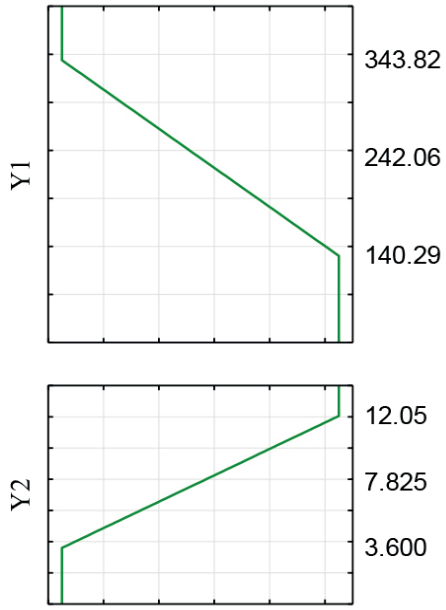

Figure 4 Graphical representation of the procedure for finding the optimal factors values of the warehouse work of the function profile $-Z$ 
1

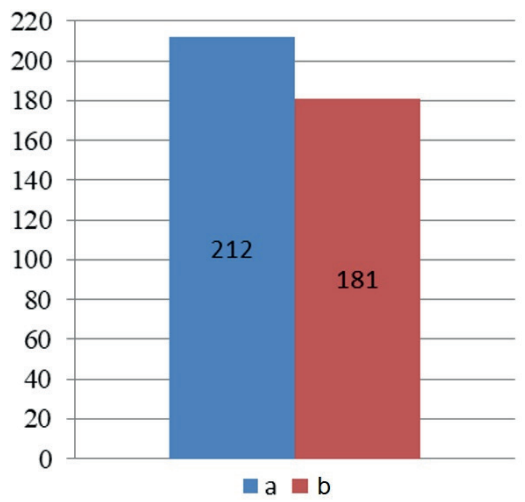

2

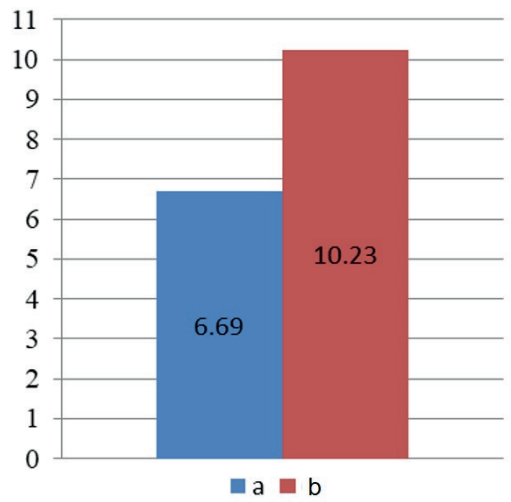

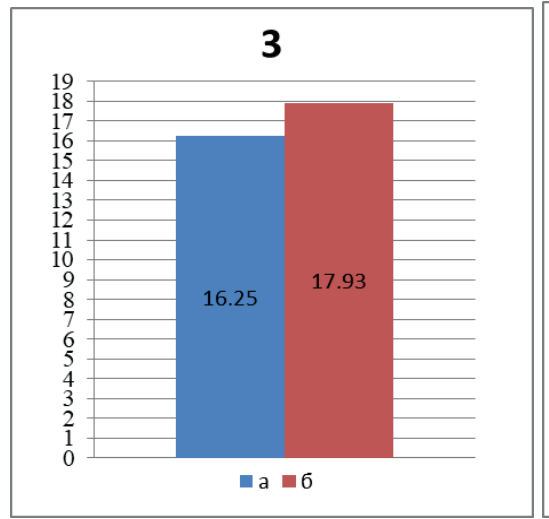
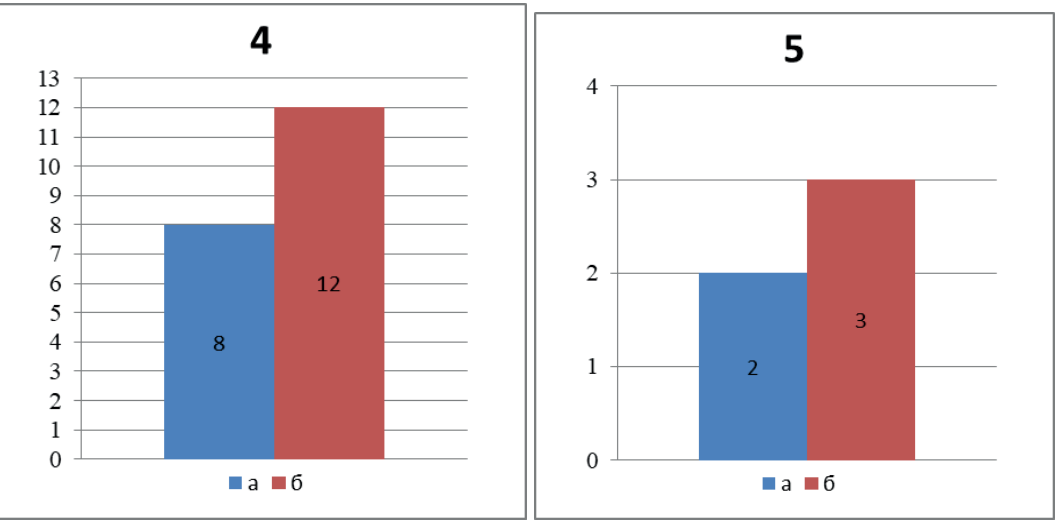

Figure 5 Average results of the warehouse functioning according to the base variant (a) and optimized (b):

1 - total costs (US\$/h); 2 - the input flow intensity (t/h); 3 - the output flow intensity $(t / h) ; 4$ - number of employees engaged in non-mechanized labor (empl.); 5 - number of loading and unloading machines (un)

in the analyzed experiment data. A graphical representation of this is presented in Figure 1.

It can be seen that there are no significant data dispersion, and therefore the mathematical model can be considered as certain.

The surface values of the investigated functions of the warehouse functioning process resultant features with reflections of factors values, on the scale of desirability, are identical in character and are presented in Figure 2. Levels of the function values on the scale of desirability are shown in Figure 3.

Visually analyzing these graphs, it is possible to state unequivocally that the optimal parameters of the warehouse functioning have been presented in the studied ranges of factors values $\mathrm{X}_{1}, \mathrm{X}_{2}, \mathrm{X}_{3}$. To determine the optimal values of the warehouse work efficiency, set the limits of the investigated values, which will include the entire experimental database that is available for analysis. Under these conditions, it is possible to find the required maximum values for the function. Consider the above for each factor and each function. Realization of the procedure for determining the optimum value of storage conditions is presented in Figure 4.

From Figure 4 can be seen that the optimal variant of the factors values is at the intersection of function maximum value in the defined interval of each factor. With such values of the studied factors, it is possible to state the optimality of the warehouse functioning and the positive solution of the applied problem. The results, which give an opportunity to evaluate the effectiveness of the warehouse functioning, have been shown in Figure 5 .

The formed optimal variant (Figure 5) makes it possible to increase the efficiency of the warehouse functioning. There is a decrease in total costs and increase in the intensities of the input flow and the output flow.

\section{Discussion}

\subsection{Research results discussion of the rational technology service orders formation}

An increase in efficiency of the warehouse is possible due to the proper organization of its work and providing technological operations with appropriate resources. The transposition of the warehouse into the cross-docking process with subsorting from the warehouse has been considered. The warehouse loading has been performed with an input flow intensity of $12.3 \ldots 23.56(\mathrm{t} / \mathrm{h})$. Under those conditions, the number of loading and unloading machines (Electrostacks Reath Track OMG NEOS LAT 3.0) a pcs., in the process of unloading, loading and moving consignments, has been increased. The number of workers employed in non-mechanized forms of work 
has been gained: cargo reception and stacking in the reception area (moving the respective consignments of cargo to the designated places of the reception area and its arrangement) by changing the number of employees from 1 to 2 ; cargo reception by quantity and quality: (opening of container, counting by quantity and verification of documentation, culling) by changing the number of employees from 1 to 2; completing and sending from the storage and reception areas (a consignment is formed for the relevant order, the quantity of the cargo and the type of container is determined, packaging and sealing is carried out, documents are being prepared) increase from 1 person to 3 employees. The increase of its efficiency has been shown by conducting the process of the warehouse work optimization on the formed technology and corresponding labor and mechanized resources. After conducting the experiment and the corresponding calculations, the optimal values of the studied parameters have been formed. The cargo output flow intensity is within the variation range $(12.3 \ldots 23.56(\mathrm{t} / \mathrm{h}))$ the optimum value will be $17.93(\mathrm{t} / \mathrm{h})$; the number of employees engaged in the non-mechanized labor are within the range (8...12) - optimum values of 12 workers, and loading and unloading machines (2...3) - optimal value 3 (units), which will rationally ensure the technological process of warehouse operation. Under such conditions, the average level of the warehouse operation will be 0.792 . The optimal value of the warehouse work costs will be 181.07 US $\$ / \mathrm{h}$, and cargo output flow intensity will be 10.23 $(\mathrm{t} / \mathrm{h})$. Compared to the basic variant, optimized one allows reducing the total costs by $17.2 \%$, and the output flow intensity to increase by $34.6 \%$, while the average values of the input flow intensity can be increased by $10.3 \%$. The given procedure of an increase in the efficiency of the warehouse work functioning on realization of the crossdocking procedure, with subsorting from a warehouse, reflects the positive effect for the enterprise.

\section{Conclusions}

A. It has been determined that optimum values for warehouse input flow intensity is $17.93(\mathrm{t} / \mathrm{h})$, the number of employees engaged in the non-mechanized labor - 12 empl., loading and unloading machines 3 pcs, so under such conditions the value of the warehouse work will be $181.07 \mathrm{US} \$ / \mathrm{h}$, cargo output flow intensity $-10.23(\mathrm{t} / \mathrm{h})$.

B. During the experiment on the warehouse optimization, an increase in efficiency of the warehouse operation on the implementation of the cross-docking procedure, with warehouse subsorting, has been recorded. It reflects the positive effect for the enterprise, namely reduction of the total costs by $17.2 \%$, increase of the output flow rate by $34.6 \%$, and average input flow intensity values of $10.3 \%$.

C. The experiment of an increase in the warehouse work efficiency, based on the division of labor and mechanized resources, makes it possible to organize and adapt the warehouse work to the requirements of trade networks and customers of transport logistics systems, in more detail.

\section{References}

[1] AULIN, V., LYASHUK, O., PAVLENKO, O., VELYKODNYI, D., HRYNKIV, A., LYSENKO, S., HOLUB, D., VOVK, Y., DZYURA, V., SOKOL, M. Realization of the logistic approach in the international cargo delivery system. Communications Scientific Letters of the University of Zilina [online]. 2019, 21(2), p. 3-12. ISSN 1335-4205, eISSN 2585-7878. Available from: http://komunikacie.uniza.sk/index.php/communications/article/view/1462

[2] KARPENKO, O., HORBENKO, A., VOVK, Y., TSON, O. Research of the structure and trends in the development of the logistics market in Ukraine. Journal of Sustainable Development of Transport and Logistics [online]. 2017, 2(2), p. 57-66. ISSN 2520-2979. Available from: http://dx.doi.org/10.14254/jsdtl.2017.2-2.5

[3] SAVIN, G., BRONNIKOV, S. Design to the city transport and logistics system in the conditions of increase of rates of institutional and technological changes. Business Logistics in Modern Management. 2018, Proceedings of the 18th International Scientific Conference Business Logistics in Modern Management, p. 485-500. ISSN 1849-5931.

[4] BAKHTIZIN, R., EVTUSHENKO, E., BURENINA, I., GAISINA, L., SAGITOV, S. Methodical approach to design of system of the logistic centers and wholesale warehouses at the regional level. Journal of Advanced Research in Law and Economics [online]. 2016, 7(1), p. 16-25. ISSN 2068-696X. Available from: https://journals.aserspublishing.eu/jarle/ article/view/235

[5] RUSHTON, A., CROUCHER, P., BAKER, P. The handbook of logistics and distribution management: understanding the supply chain. 5. ed. India: Replika Press Pvt Ltd, Kogan Page Publishers, 2014. ISBN 978-0749466275.

[6] HESSE, M., RODRIGUE, J.-P.: The transport geography of logistics and freight distribution. Journal of Transport Geography [online]. 2004, 12(3), p. 171-184. ISSN 0966-6923, eISSN 1873-1236. Available from: https://doi.org/10.1016/j.jtrangeo.2003.12.004

[7] PIECYK, M. I., MCKINNON, A. C. Forecasting the carbon footprint of road freight transport in 2020. International Journal of Production Economics [online]. 2010, 128(1), p. 31-42. ISSN 0925-5273, eISSN 1873-7579. Available from: https://doi.org/10.1016/j.ijpe.2009.08.027 
[8] SIAU, K., TIAN, Y. Supply chains integration: architecture and enabling technologies. Journal of Computer Information Systems. 2004, 44(3), p. 67-72. ISSN 0887-4417.

[9] DENNIS, W. T. Parcel and small package delivery industry. North Charleston, SC: CreateSpace Independent Publishing Platform, 2011. ISBN 978-1461021544.

[10] KAPSKI, D., KASYANIK, V., LOBASHOV, O., VOLYNETS, A., KAPTSEVICH, O., GALKIN, A. Estimating the parameters of traffic flows on the basis of processing of localization data on the movement of vehicles. Communications Scientific Letters of the University of Zilina [online]. 2019, 21(2), p. 89-99. ISSN 1335-4205, eISSN 2585-7878. Available from: http://komunikacie.uniza.sk/index.php/communications/article/view/1474

[11] NARASIMHAN, R., KIM, S. W. Information system utilization strategy for supply chain integration. Journal of Business Logistics [online]. 2001, 22(2), p. 51-75. eISSN 2158-1592. Available from: https://doi.org/10.1002/j.2158-1592.2001.tb00003.x

[12] VELYCHKO, O., VELYCHKO, L. Logistical modelling of managerial decisions in social and marketing business systems. Journal of International Studies [online]. 2017, 10(3), p. 206-219. ISSN 0910-5476. Available from: https://doi.org/10.14254/2071-8330.2017/10-3/15

[13] KOT, S., GOLDBACH, I. R., SLUSARCZYK, B. Supply chain management in SMEs - Polish and Romanian approach. Economics and Sociology [online]. 2018, 11(4), p. 142-156. ISSN 2071-789X. Available from: https://doi.org/10.14254/2071-789X.2018/11-4/9

[14] LEVINSON, M. The Box: how the shipping container made the world smaller and the world economy bigger-with a new chapter by the author. 2. ed. USA: Princeton University Press, 2016. ISBN 978-0691136400.

[15] WALISZEWSKI, J. M. Towards understanding the impacts of congestion pricing on urban trucking. PhD Thesis. Cambridge, MA, USA: Massachusetts Institute of Technology, 2005.

[16] AULIN, V., HRYNKIV, A., LYSENKO, S., DYKHA, A., ZAMOTA, T., DZYURA, V. Exploring a possibility to control the stressed-strained state of cylinder liners in diesel engines by the tribotechnology of alignment. Eastern-European Journal of Enterprise Technologies [online]. 2019, 3(12-99), p. 6-16. ISSN 1729-3774, eISSN 1729-4061. Available from: https://doi.org/10.15587/1729-4061.2019.171619

[17] AULIN, V., HRYNKIV, A., LYSENKO, S., ROHOVSKII, I., CHERNOVOL, M., LYASHUK, O., ZAMOTA, T. Studying truck transmission oils using the method of thermaloxidative stability during vehicle operation. Eastern-European Journal of Enterprise Technologies [online]. 2019, 1(6-97), p. 6-12. ISSN 1729-3774, eISSN 1729-4061. Available from: https://doi.org/10.15587/1729-4061.2019.156150

[18] AULIN, V., HRINKIV, A., DYKHA, A., CHERNOVOL, M., LYASHUK, O., LYSENKO, S. Substantiation of diagnostic parameters for determining the technical condition of transmission assemblies in trucks. Eastern-European Journal of Enterprise Technologies [online]. 2018, 2(1-92), p. 4-13. ISSN 1729-3774, eISSN 1729-4061. Available from: https://doi.org/10.15587/1729-4061.2018.125349

[19] GRABARA, J., BAJDOR, P., OKWIET, B. Center as a tool for logistics activities in support of the company on the example of SME's enterprise X. Polish Journal of Management Studies. 2010, 2, p. 35-43. ISSN 2081-7452.

[20] WEIDINGER, F., BOYSEN, N., SCHNEIDER, M. Picker routing in the mixed-shelves warehouses of e-commerce retailers. European Journal of Operational Research [online]. 2019, 274(2), p. 501-515. ISSN 0377-2217. Available from: https://doi.org/10.1016/j.ejor.2018.10.021

[21] TANAKA, R., ISHIGAKI, A., SUZUKI, T., HAMADA, M., KAWAI, W. Shipping plan for apparel products using shipping record and just-in-time inventory at a logistics warehouse. In: 7th International Congress on Advanced Applied Informatics IIAI-AAI 2018 : proceedings. 2019. eISBN 9781538674475, p. 682-687.

[22] GRAWE, S. J. Logistics innovation: a literature-based conceptual framework. The International Journal of Logistics Management [online]. 2009, 20(3), p. 360-377. ISSN 0957-4093. Available from: https://doi.org/10.1108/09574090911002823

[23] SMITH, D., SRINIVAS, S. A simulation-based evaluation of warehouse check-in strategies for improving inbound logistics operations. Simulation Modelling Practice and Theory [online]. 2019, 94, p. 303-320, 2019. ISSN 1569-190X, eISSN 1878-1462. Available from: https://doi.org/10.1016/j.simpat.2019.03.004

[24] KOVACS, G., KOT, S. Economic and social effects of novel supply chain concepts and virtual enterprises. Journal of International Studies [online]. 2017, 10(1), p. 237-254. ISSN 2071-8330, eISSN 2306-3483. Available from: https://doi.org/10.14254/2071-8330.2017/10-1/17

[25] GERINI, C., SCIOMACHEN, A. Evaluation of the flow of goods at a warehouse logistic department by Petri Nets. Flexible Services and Manufacturing Journal [online]. 2019, 31(2), p. 354-380. ISSN 1936-6582, eISSN $1936-6590$. Available from: https://doi.org/10.1007/s10696-018-9312-3

[26] MOODY, J. O., ANTSAKLIS, P. J. Supervisory control of discrete event systems using Petri nets [online]. New York: Springer Science \& Business Media, 2012. ISBN 978-0-7923-8199-0, eISBN 978-1-4615-5711-1. Available from: https://doi.org/10.1007/978-1-4615-5711-1

[27] AULIN, V., LYASHUK, O., TYKHYI, A., KARPUSHYN, S., DENYSIUK, N. Influence of rheological properties of a soil layer adjacent to the working body cutting element on the mechanism of soil cultivation. Acta Technologica Agriculturae [online]. 2018, 21(4), p. 153-159. ISSN 1338-5267. Available from: https://doi.org/10.2478/ata-2018-0028 
[28] OH, S. Comparative study on value determining factors of factory and logistics warehouse. International Journal of Innovative Technology and Exploring Engineering. 2019, 8(8S2), p. 1025-1030. ISSN 2278-3075.

[29] PETKOVIC, T., PULJIZ, D., MARKOVIC, I., HEIN, B. Human intention estimation based on hidden Markov model motion validation for safe flexible robotized warehouses. Robotics and Computer-Integrated Manufacturing [online]. 2019, 57, p. 182-196. ISSN 0736-5845, eISSN 1879-2537. Available from: https://doi.org/10.1016/j.rcim.2018.11.004

[30] AULIN, V., LYSENKO, S., LYASHUK, O., HRINKIV, A., VELYKODNYI, D., VOVK, Y., HOLUB, D., CHERNAI, A. Wear resistance increase of samples tribomating in oil composite with geo modifier KGMF-1. Tribology in Industry [online]. 2019, 41(2), p. 156-165. ISSN 0354-8996, eISSN 2217-7965. Available from: https://doi.org/10.24874/ti.2019.41.02.02

[31] CAMPOLONGO, F., BRADDOCK, R. The use of graph theory in the sensitivity analysis of the model output: a second order screening method. Reliability Engineering \& System Safety. 1999, 64(1), p. 1-12. ISSN 0951-8320.

[32] BOYSEN, N., BRISKORN, D., FEDTKE, S., SCHMICKERATH, M. Automated sortation conveyors: A survey from an operational research perspective. European Journal of Operational Research [online]. 2019, 276(3), p. 796-815. ISSN 0377-2217. Available from: https://doi.org/10.1016/j.ejor.2018.08.014

[33] GLOVER, F., KLINGMAN, D., PHILLIPS, N. V. Network models in optimization and their applications in practice. 1. ed. USA: John Wiley \& Sons, 1992. ISBN 978-0471571384.

[34] BOYSEN, N., de KOSTER, R., WEIDINGER, F. Warehousing in the e-commerce era: a survey. European Journal of Operational Research [online]. 2019, 277(2), p. 396-411. ISSN 0377-2217. Available from: https://doi.org/10.1016/j.ejor.2018.08.023

[35] MAHROOF, K. A human-centric perspective exploring the readiness towards smart warehousing: the case of a large retail distribution warehouse. International Journal of Information Management [online]. 2019, 45, p. 176-190. ISSN 0268-4012, eISNN 0143-6236. Available from: https://doi.org/10.1016/j.ijinfomgt.2018.11.008

[36] YOSHITAKE, H., KAMOSHIDA, R., NAGASHIMA, Y. New automated guided vehicle system using real-time holonic scheduling for warehouse picking. IEEE Robotics and Automation Letters [online]. 2019, 4(2), 8618437, p. $1045-1052$. ISSN 377-3766. Available from: https://doi.org/10.1109//ra.2019.2894001

[37] HARMON, R. L. Reinventing the warehouse: world class distribution logistics. 1. ed. The Free Press, 1993. ISBN 978-0029138632.

[38] HARRINGTON, Jr., E. C. The desirability function. Industrial Quality Control. 1965, 21, p. 494-498. ISSN 0884-822X. 